Article

\title{
Zn-Al Layered Double Hydroxide Thin Film Fabricated by the Sputtering Method and Aqueous Solution Treatment
}

\author{
Jaehwan Shin, Kyunghwan Kim and Jeongsoo Hong *(1) \\ Department of Electrical Engineering, Gachon University, Incheon 13120, Korea; sjhjuk@naver.com (J.S.); \\ khkim@gachon.ac.kr (K.K.) \\ * Correspondence: hongjs@gachon.ac.kr; Tel.: +82-31-750-5560
}

Received: 2 June 2020; Accepted: 7 July 2020; Published: 13 July 2020

check for updates

\begin{abstract}
Zn-Al layered double hydroxides (LDHs) were synthesized herein via a simple process. First, Al-doped $\mathrm{ZnO}$ film was deposited onto a glass substrate using the facing target sputtering system. Successful synthesis of the $\mathrm{Zn}-\mathrm{Al} \mathrm{LDH}$ was achieved via a treatment process using an aqueous solution which contains $\mathrm{NO}_{3}{ }^{-}$anions. X-ray diffraction analysis confirmed that it was consistent with the previous $\mathrm{Zn}-\mathrm{Al} \mathrm{LDH}$ synthesis experiment data, and the calculated $d$-value was 9.1 A. Scanning electron microscopy observations revealed that the as-synthesized sample had a plate-like structure.
\end{abstract}

Keywords: Zn-Al; layer double hydroxide; sputter; solution process

\section{Introduction}

Layered double hydroxides (LDHs) comprise anions that are interchangeable with different metal cations of $\mathrm{M}^{2+} / \mathrm{M}^{3+}$ with an octahedral brucite structure [1]. As shown in Figure 1, LDH exhibits strong binding in the $\mathrm{XY}$ plane, and the anions inserted between floors are easily exchanged owing to weak binding forces between layers [2]. Using these characteristics, LDH is being studied not only as an anionic exchange agent, catalyst, photocatalyst, and for hydrogen production and $\mathrm{CO}_{2}$ capture, but also for resistive random access memory (ReRAM) applications [3-8].

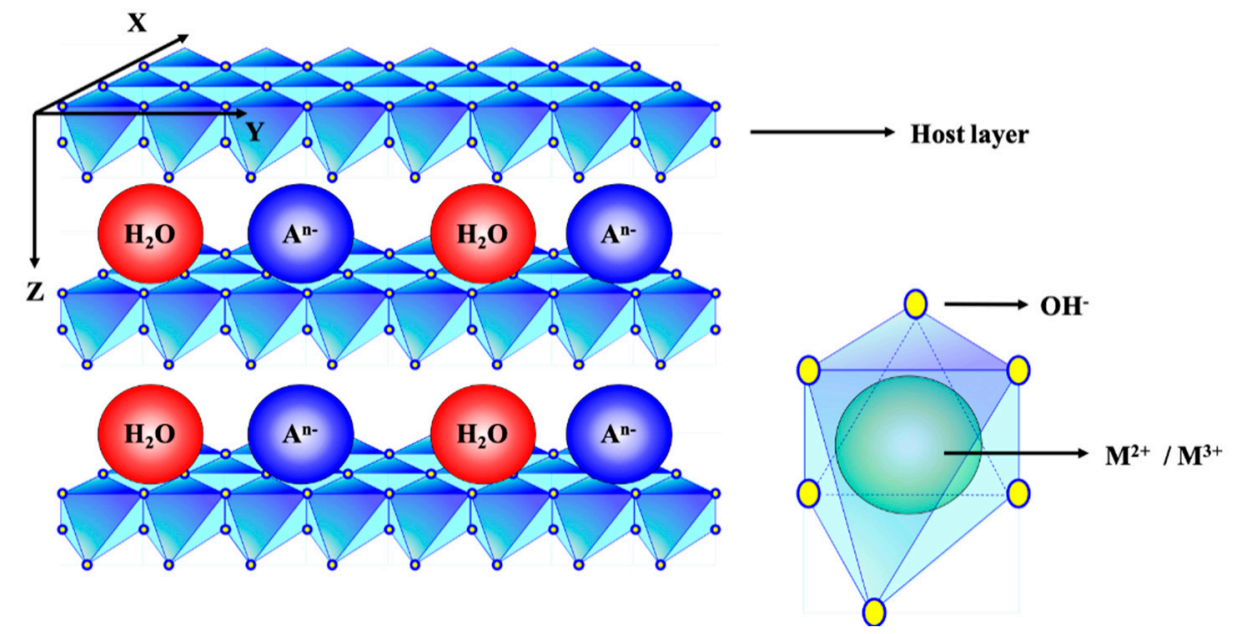

Figure 1. Structure of layered double hydroxides. 
General Equation: $\left[\mathrm{M}_{1-\mathrm{x}}{ }^{2+} \mathrm{M}_{\mathrm{x}}{ }^{3+}(\mathrm{OH})_{2}\right]^{\mathrm{x}+}\left[\left(\mathrm{A}^{\mathrm{m}-}\right)_{\mathrm{x} / \mathrm{m}} \cdot \mathrm{nH}_{2} \mathrm{O}\right]^{\mathrm{x}-},\left[\mathrm{M}^{2+}: \mathrm{Ca}^{2+}, \mathrm{Mg}^{2+}, \mathrm{Zn}^{2+}, \mathrm{Ni}^{2+}\right.$, $\mathrm{Co}^{2+}, \mathrm{Fe}^{2+}$, and etc. $/ \mathrm{M}^{3+}: \mathrm{Al}^{3+}, \mathrm{Cr}^{3+} . \mathrm{Co}^{3+}, \mathrm{Fe}^{3+}$, and etc. $],\left[\mathrm{A}_{\mathrm{m}-}: \mathrm{CO}_{3}{ }^{2-}, \mathrm{NO}_{3}{ }^{-}, \mathrm{Cl}^{-}, \mathrm{SO}_{4}{ }^{-}\right.$, and etc.] [9].

LDH can synthesize various types of LDH by changing two metal cations and anions inserted between layers. Among them, we tried to synthesize LDH due to the photocatalytic properties of $\mathrm{ZnO}$ in order to apply LDH to the photocatalytic field. In addition, by selecting $\mathrm{Al}$-which has a relatively low electronegativity among the trivalent metal elements corresponding to $\mathrm{M}^{3+}$-it was expected to improve the photocatalytic properties when synthesizing $\mathrm{Zn}-\mathrm{Al} \mathrm{LDH}$.

For the synthesis of LDH, the coprecipitation method and hydrothermal method have mainly been used $[10,11]$. However, these are complex processes that can enable fabrication of only powder samples. Moreover, conventional synthesis methods are sensitive to solution conditions such as $\mathrm{pH}$ and temperature during the reaction process, and their shapes and crystallographic properties are easily altered. Therefore, a simpler and more effective process for the synthesis of LDH is required.

In order to apply it to more diverse fields such as photocatalyst in actual applications, LDH other than the powder type is required. Therefore, research on thin film (TF)-LDH grown on a substrate using metal substrate has been actively conducted $[12,13]$. However, it is difficult to control the band gap of LDH when using a metal substrate. Therefore, we focused on the previous metal oxide-based LDH synthesis study [14] and we aim to fabricate LDH containing a host layer, which corresponds to $\mathrm{Al}$ doped $\mathrm{ZnO}(\mathrm{AZO})$. If a host layer of $\mathrm{AZO}$ is present, the organic decomposition reaction occurs via the photocatalytic reaction of $\mathrm{ZnO}$, and the band energy can be controlled using UV irradiation [15]. When applied to the field of photocatalysts, the wide absorbance of $\mathrm{Zn}-\mathrm{Al} \mathrm{LDH}$ can be expected to increase the efficiency of light energy.

\section{Materials and Methods}

First, AZO thin films were deposited using facing targets sputtering (FTS) system for fabrication of $\mathrm{Zn}-\mathrm{Al}$ LDH [16-18] (Figure 2). The FTS system possesses a structure in which two targets face each other, and the substrate is positioned perpendicular to the center of the two targets to minimize damage to it. In addition, secondary electrons reciprocating between the two targets promote ionization of the gas because of the confining magnetic field. They form a high-density plasma, which enables higher deposition rates and improved thin film deposition when compared to that achieved using existing sputtering equipment.

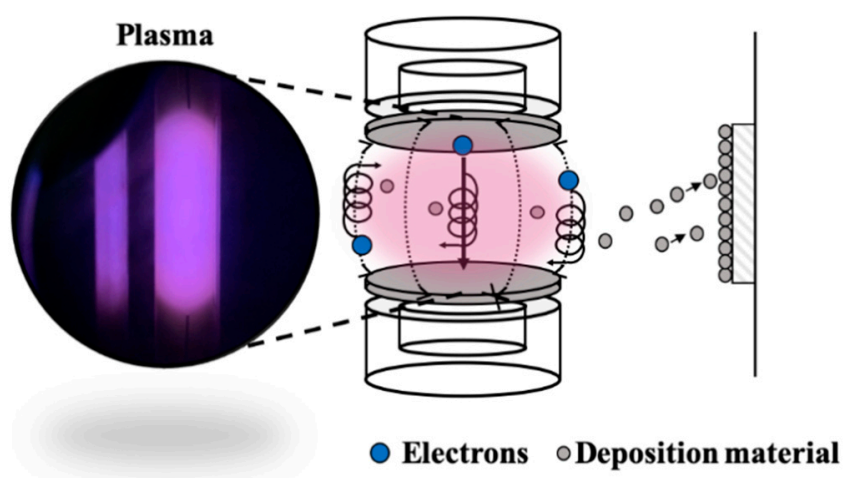

Figure 2. Schematic image of the facing targets sputtering (FTS) system.

Samples were deposited onto a glass substrate using the FTS system with AZO targets. The substrate was washed with a mixture of hydrogen peroxide $\left(\mathrm{H}_{2} \mathrm{O}_{2}, 30 \%\right.$, Wako, Japan), ammonia solution $\left(\mathrm{NH}_{3}, 28 \%\right.$, Wako), and DI water, followed by washing with an ultrasonic cleaner. Subsequently, ultrasonic cleaning with acetone and ethanol distilled water was performed, and the washed substrate was dried using nitrogen gas. Table 1 summarizes the sputtering conditions. 
Table 1. Sputtering conditions.

\begin{tabular}{cc}
\hline Parameters & Conditions \\
\hline Target & $\mathrm{Al}$ doped $\mathrm{ZnO}, 4$ inch $\left(\mathrm{Zn:} 98 \mathrm{wt} . \%, \mathrm{Al}_{2} \mathrm{O}_{3}{ }^{-}: 2 \mathrm{wt} . \%\right)$ \\
Substrate & Glass \\
Working pressure & $2 \mathrm{mTorr}$ \\
Gas flow & $\mathrm{Ar}, 10 \mathrm{sccm}, \mathrm{O}_{2}, 0.8 \mathrm{sccm}$ \\
Input power & $500 \mathrm{~W}(\mathrm{DC})$ \\
Thickness & $100 \mathrm{~nm}$ \\
\hline
\end{tabular}

After AZO thin film deposition, a solution containing $\mathrm{NO}_{3}{ }^{-}$anions was prepared to synthesize $\mathrm{Zn}-\mathrm{Al} \mathrm{LDH}$ with anions inserted between the host layers. Zinc nitrate hexahydrate $\left(\mathrm{Zn}\left(\mathrm{NO}_{3}\right)_{2} 6 \mathrm{H}_{2} \mathrm{O}\right.$, $95 \%$, DUKSAN) was added to DI water. The chemical composition of the actual synthesized LDH is different from the ratio of the actual deposited AZO film. Based on a general equation, LDH is formed. Additionally, LDH can be synthesized with a small amount of $\mathrm{Al}^{3+}$ ions $[19,20]$. During the treatment process, conditions such as molar concentration $(0.2,0.3,0.4,0.5 \mathrm{M})$ and solution temperature $(60,70$, $80,90^{\circ} \mathrm{C}$ ) were varied; the samples were heated for $30 \mathrm{~min}$ and dried using nitrogen gas, and variations in their properties were evaluated.

X-ray diffraction (XRD, MPA-2000, Rigaku, Japan, Step—0.05 [degree], Speed-5 [degree/min]) was used to evaluate the crystallographic properties, including basal spacing and crystallinity. The surface morphologies of the samples were observed via scanning electron microscopy (SEM, S-4700, Hitachi, Japan). Ultraviolet-visible spectroscopy (Lambda 750 UV-vis-NIR, Perkin Elmer, Waltham, MA, USA) and Fourier-transform infrared spectroscopy (FT-IR with Raman/NIR, FEI Company, Hillsboro, OR, USA) were used to investigate the optical properties.

\section{Results}

Figure 3 shows the XRD patterns of AZO thin films and the samples treated with an aqueous solution with different molar concentrations. In the case of the AZO thin films, the (002) peak was observed at $34.5^{\circ}$ (JCPDS 36-1451); however, all the samples treated with the solution with different molar concentrations exhibited the (003) peak at approximately $10^{\circ}$. The samples treated at $0.2 \mathrm{M}$ still showed the (002) peak, which disappeared from the other samples. This result means that the high molar concentration of the $\mathrm{NO}_{3}{ }^{-}$solution promoted a reaction with the $\mathrm{AZO}$ thin film owing to the increase in the number of $\mathrm{NO}_{3}{ }^{-}$ions, leading to the reduction in the (002) peak of the host layer. Even if the reaction time and solution temperature were the same, a high molar concentration did not result in a peak in the host layer being exhibited. It was assumed that obtaining the LDH peak whilst maintaining the peak in the host layer is a better characteristic.

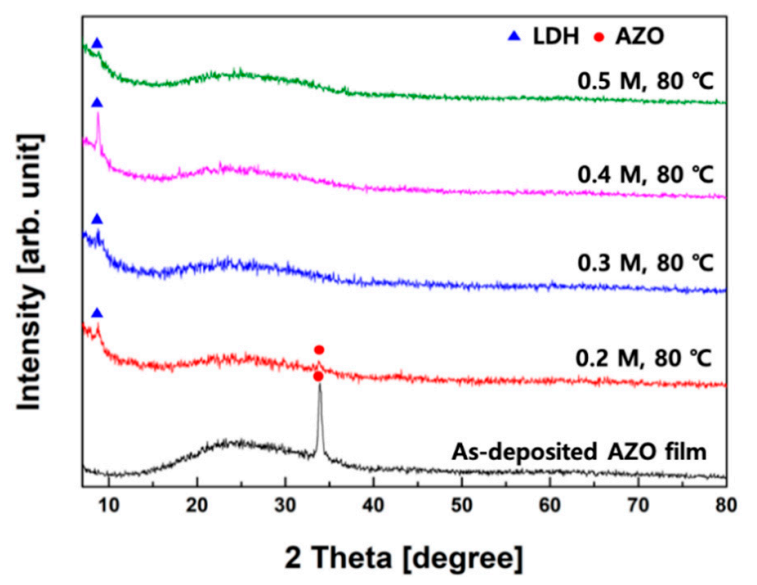

Figure 3. X-ray diffraction (XRD) patterns of $\mathrm{AZO}$ thin film and $\mathrm{Zn}-\mathrm{Al} \mathrm{LDH}$ with different molar concentrations. 
The basal spacing ( $d$-value) was also calculated and Table 2 shows the $d$-value for each sample synthesized at different molar concentrations. However, it was observed that the $d$-value did not change for all the samples synthesized at different molar concentrations [20]. The $d$-value of the (003) peak in LDH is an important factor that shows the change in intercalated material between layers. From the XRD results, we confirmed the presence of the (003) peak and the LDH synthesis by obtaining the interplanar spacing between layers. It was also confirmed that the AZO thin film prepared by sputtering was formed to $\mathrm{Zn}-\mathrm{Al} \mathrm{LDH}$ through solution treatment.

Table 2. $d$-values of each sample calculated by the XRD result.

\begin{tabular}{ccc}
\hline Sample & 2 Theta(degree) & $\boldsymbol{d}$-Value( $(\AA)$ \\
\hline $\mathrm{AZO}(002)$ & 34.5 & 2.598 \\
$0.2 \mathrm{M}, 80^{\circ} \mathrm{C}$ & 9.692 & 9.121 \\
$0.3 \mathrm{M}, 80^{\circ} \mathrm{C}$ & 9.703 & 9.110 \\
$0.4 \mathrm{M}, 80^{\circ} \mathrm{C}$ & 9.685 & 9.127 \\
$0.5 \mathrm{M}, 80^{\circ} \mathrm{C}$ & 9.734 & 9.081 \\
\hline
\end{tabular}

In this study, we attempted to synthesize LDH containing the host layer (002) peak of AZO which has the $\mathrm{ZnO}$ photocatalytic reaction. Therefore, considering the XRD results, $0.2 \mathrm{M}$ was considered as the optimal molar concentration for LDH synthesis owing to the presence of the peak of the host layer. Thus, the experiment was conducted to determine the change according to the heating temperature at molar concentration of $0.2 \mathrm{M}$.

Figure $4 \mathrm{a}$ indicates the XRD patterns of all the samples synthesized at $0.2 \mathrm{M}$ for $30 \mathrm{~min}$ at different heating temperatures. The sample synthesized at $60^{\circ} \mathrm{C}$ exhibited (003) and (006) peaks at approximately $10^{\circ}$ and $19^{\circ}$, respectively. The AZO (002) peak $\left(34.5^{\circ}\right)$ of the host layer was also observed. On the other hand, the sample synthesized at $70^{\circ} \mathrm{C}$ or more did not show a clear peak at approximately $19^{\circ}$. The sample synthesized at above $90{ }^{\circ} \mathrm{C}$ was assumed to reduce the (002) peak of the host layer by promoting the reaction at a high solution temperature. The presence of (006) peaks shows that growth is better in the (001) direction, and that crystallographic properties are better than when only (003) peaks are present. In addition, it was confirmed through the $d$-value of the (003) peak that the material inserted between layers was $\mathrm{NO}_{3}{ }^{-}$in all the samples synthesized at $0.2 \mathrm{M}$.

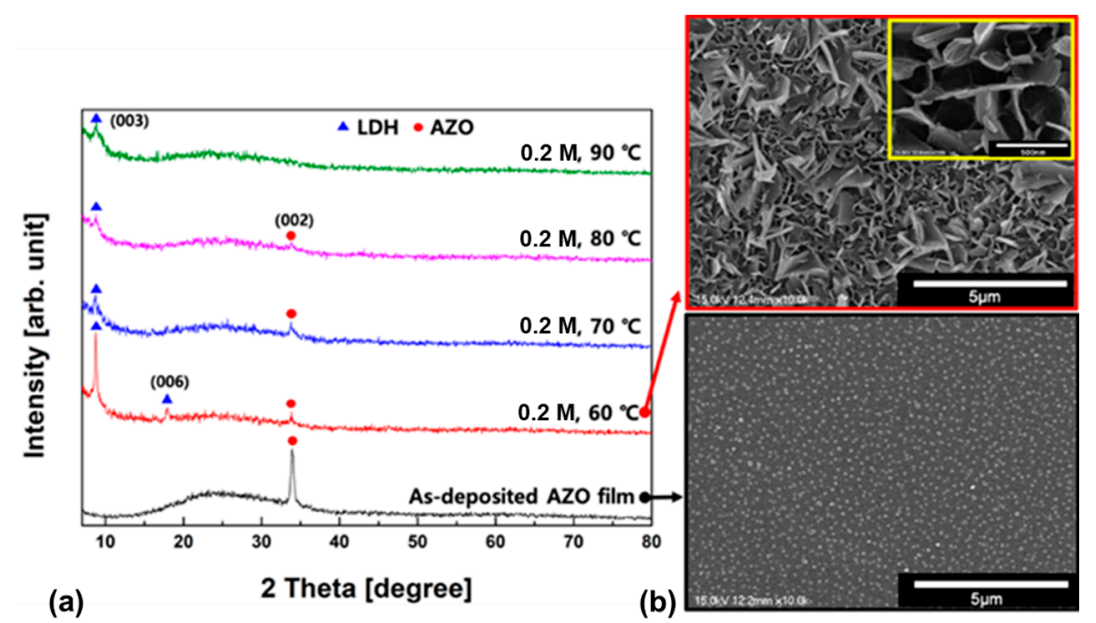

Figure 4. (a) XRD patterns of the samples with various heating temperatures, (b) surface morphologies of $\mathrm{AZO}$ and $\mathrm{Zn}-\mathrm{Al}$ layered double hydroxides (LDHs).

Table 3 shows the $d$-value for each sample synthesized at different heating temperatures. Even when the heating temperature increased from $60^{\circ} \mathrm{C}$ to $90^{\circ} \mathrm{C}$, no significant change was observed. 
Table 3. Distance calculated by XRD result.

\begin{tabular}{ccc}
\hline Sample & 2 Theta(degree) & $\boldsymbol{d}$-Value( $(\AA)$ \\
\hline $0.2 \mathrm{M}, 60^{\circ} \mathrm{C}$ & 9.636 & 9.174 \\
$0.2 \mathrm{M}, 70^{\circ} \mathrm{C}$ & 9.632 & 9.177 \\
$0.2 \mathrm{M}, 80^{\circ} \mathrm{C}$ & 9.692 & 9.121 \\
$0.2 \mathrm{M}, 90^{\circ} \mathrm{C}$ & 9.727 & 9.088 \\
\hline
\end{tabular}

Figure $4 \mathrm{~b}$ shows that AZO thin films generally exhibit dense surfaces [21], but show a rough surface structure after aqueous solution treatment. The solution-treated samples shows the plate-like structural characteristic of LDH, and we confirmed the formation of hexagonally-shaped plate-like particles of LDH at $100 \mathrm{k}$ magnification [22].

In Figure $5 \mathrm{a}$, the UV-vis measurements show that the samples synthesized at $0.2 \mathrm{M}$ and $60{ }^{\circ} \mathrm{C}$ for 30 min did not differ significantly from the AZO thin film, but the samples synthesized at temperatures above $70^{\circ} \mathrm{C}$ exhibited higher transmittance than the AZO thin film. LDH was synthesized using AZO thin film with an aqueous solution treatment; hence, the thickness of thin film was reduced. The thickness of the thin film was reduced via LDH synthesis, and the decrease in absorbance in the relationship of $\mathrm{A}=-\log \mathrm{T}$ was attributed to the increase in transmittance (Beer-Lambert law). Therefore, the reduced thickness of the thin film resulted in the decrease in the optical path length, which led to a decrease in absorbance.
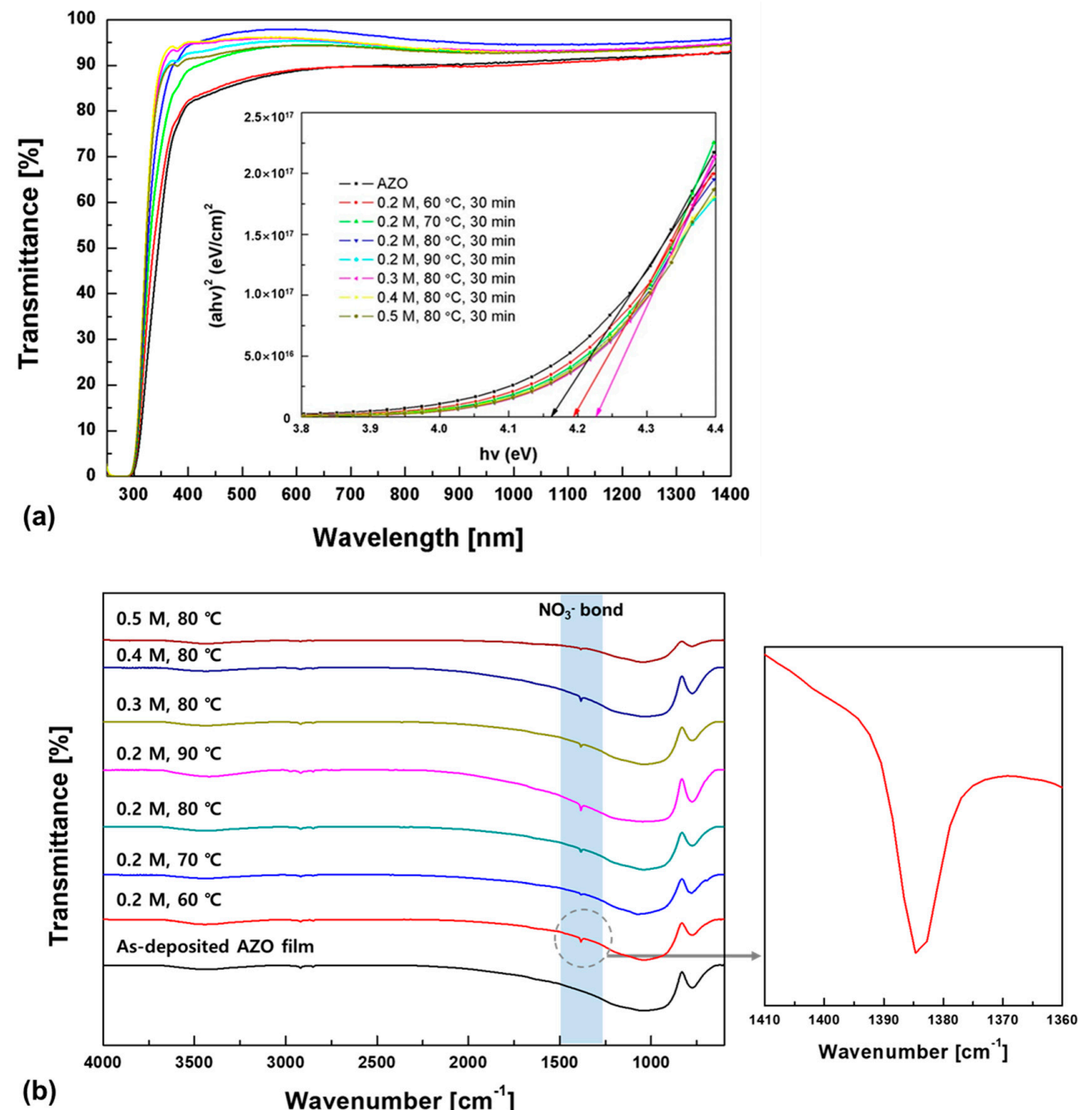

Figure 5. (a) Transmittance of all the samples, inset is optical bandgap energies; (b) Fourier-transform infrared spectroscopy (FT-IR) spectra of all the samples. 
In the case of the optical band gap energy $\left(\mathrm{E}_{\mathrm{g}}\right)$, conventional $\mathrm{ZnO}$ is approximately $3.4 \mathrm{eV}$ [23], but that of the synthesized AZO thin film was $4.18 \mathrm{eV}$. This can be explained by the Burstein-Moss effect, according to which free electrons grown by Al-doping raise the Fermi level by filling the conduction band. At this time, the carrier concentration and energy band gap increased, and the wavelength band shifted to that of the blue wavelength, resulting in a blue shift [24]. LDH values ranged between 4.21 and $4.23 \mathrm{eV}$, and showed no significant trends regarding molarity or temperature.

Figure $5 \mathrm{~b}$ shows the FT-IR spectra of the samples. We performed FT-IR measurements to determine whether the intercalation ions were $\mathrm{NO}_{3}{ }^{-}$ions. The results showed that all the samples, except the AZO thin film, exhibited a $\mathrm{NO}_{3}{ }^{-}$peak near $1385 \mathrm{~cm}^{-1}$. This result is in agreement with the reference data, and we confirmed that the synthesized $\mathrm{LDH}$ contains $\mathrm{NO}_{3}{ }^{-}$bonds [25].

\section{Conclusions}

$\mathrm{Zn}-\mathrm{Al} \mathrm{LDH}$ was synthesized and all the samples were confirmed to exhibit a (003) peak. It was determined that $0.2 \mathrm{M}$ was the optimum molar concentration with the host layer peak and LDH peak. The characteristics of the synthesized LDH were confirmed by changing the heating temperature at $0.2 \mathrm{M}$ and, as a result, the (006) peak was observed at $60^{\circ} \mathrm{C}$ and the $\mathrm{LDH}$ synthesized at 60,70 , and $80^{\circ} \mathrm{C}$ still exhibited the host layer peak. All the samples exhibited high transmittance and FT-IR measurements confirmed that the synthesized $\mathrm{LDH}$ contained an $\mathrm{NO}_{3}{ }^{-}$bond found at approximately $1385 \mathrm{~cm}^{-1}$.

Author Contributions: Conceptualization, J.S. and J.H.; methodology, K.K. and J.H.; validation, J.S. and J.H.; investigation, J.S., K.K., and J.H.; writing — original draft preparation, J.S.; writing—review and editing, K.K. and J.H. All authors have read and agreed to the published version of the manuscript.

Funding: This research was supported by the Gachon University research fund of 2018 (GCU-2018-0286), the Korea Institute of Energy Technology Evaluation and Planning (KETEP) and the Ministry of Trade, Industry \& Energy (MOTIE) of Korea (No. 20194030202290).

Conflicts of Interest: The authors declare no conflict of interest.

\section{References}

1. Al Ali, S.H.; Al-Qubaisi, M.; Hussein, M.Z.; Ismail, M.; Zainal, Z.; Hakim, M.N. Controlled release and angiotensin-converting enzyme inhibition properties of an antihypertensive drug based on a perindopril erbumine-layered double hydroxide nanocomposite. Int. J. Nanomed. 2012, 7, 2129-2141. [CrossRef]

2. Elkhattabi, E.H.; Badreddine, M.; Berraho, M.; Legrouri, A. Incorporation of fluorophosphate into zinc-aluminium-nitrate layered double hydroxide by ion exchange. Bull. Mater. Sci. 2012, 35, 693-700. [CrossRef]

3. Prasanna, S.V.; Kamath, P.V. Anion-Exchange Reactions of Layered Double Hydroxides: Interplay between Coulombic and H-Bonding Interactions. Ind. Eng. Chem. Res. 2009, 48, 6315-6320. [CrossRef]

4. Xu, M.; Wei, M. Layered Double Hydroxide-Based Catalysts: Recent Advances in Preparation, Structure, and Applications. Adv. Funct. Mater. 2018, 28, 1802943. [CrossRef]

5. Abderrazek, K.; Najoua, F.S.; Srasra, E. Synthesis and characterization of [Zn-Al] LDH: Study of the effect of calcination on the photocatalytic activity. Appl. Clay Sci. 2016, 119, 229-235. [CrossRef]

6. Wang, W.; Xu, Z.; Guo, Z.; Jiang, C.; Chu, W. Layered double hydroxide and related catalysts for hydrogen production and a biorefinery. Chin. J. Catal. 2015, 36, 139-147. [CrossRef]

7. Ram Reddy, M.K.; Xu, Z.P.; Lu, G.Q.; Diniz da Costa, J.C. Layered Double Hydroxides for $\mathrm{CO}_{2}$ Capture: Structure Evolution and Regeneration. Ind. Eng. Chem. Res. 2006, 45, 7504-7509. [CrossRef]

8. Yang, F.; Kadhim, M.S.; Babiker, M.; Elshekh, H.; Hou, W.; Huang, G.; Zhang, Y.; Zhao, Y.; Sun, B. Ion reaction tunable ON/OFF ratio of vertically oriented $\mathrm{Zn}$-Al layered-double-hydroxide nanosheets based memristor. Mater. Today Commun. 2019, 20, 100573. [CrossRef]

9. Hobbs, C.; Jaskaniec, S.; McCarthy, E.K.; Downing, C.; Opelt, K.; Güth, K.; Shmeliov, A.; Mourad MC, D.; Mandel, K.; Nicolosi, V. Structural transformation of layered double hydroxides: An in situ TEM analysis. npj 2D Mater. Appl. 2018, 2, 1-10. [CrossRef] 
10. Chang, Z.; Evans, D.G.; Duan, X.; Vial, C.; Ghanbaja, J.; Prevot, V.; De Roy, M.; Forano, C. Synthesis of $\left[\mathrm{Zn}-\mathrm{Al}-\mathrm{CO}_{3}\right]$ layered double hydroxides by a coprecipitation method under steady-state conditions. J. Solid State Chem. 2005, 178, 2766-2777. [CrossRef]

11. Xu, Z.P.; Lu, G.Q. Hydrothermal synthesis of layered double hydroxides (LDHs) from mixed $\mathrm{MgO}$ and $\mathrm{Al}_{2} \mathrm{O}_{3}$ : LDH formation mechanism. Chem. Mater. 2005, 17, 1055-1062. [CrossRef]

12. Mikhailau, A.; Maltanava, H.; Poznyak, S.K.; Salak, A.N.; Zheludkevich, M.L.; Yasakau, K.A.; Ferreira, M.G. One-step synthesis and growth mechanism of nitrate intercalated ZnAl LDH conversion coatings on zinc. Chem. Commun. 2019, 55, 6878-6881. [CrossRef] [PubMed]

13. Neves, C.S.; Bastos, A.C.; Salak, A.N.; Starykevich, M.; Rocha, D.; Zheludkevich, M.L.; Cunha, A.; Almeida, A.; Tedim, J.; Ferreira, M.G. Layered double hydroxide clusters as precursors of novel multifunctional layers: A bottom-up approach. Coatings 2019, 9, 328. [CrossRef]

14. Valeikiene, L.; Roshchina, M.; Grigoraviciute-Puroniene, I.; Prozorovich, V.; Zarkov, A.; Ivanets, A.; Kareiva, A. On the Reconstruction Peculiarities of Sol-Gel Derived Mg2- xMx/Al1 (M= Ca, Sr, Ba) Layered Double Hydroxides. Crystals 2020, 10, 470. [CrossRef]

15. Hong, J.; Katsumata, K.; Matsushita, N. Fabrication of Al-Doped ZnO Film with High Conductivity Induced by Photocatalytic Activity. J. Electron. Mater. 2016, 45, 4875-4880. [CrossRef]

16. Rim, Y.S.; Kim, S.M.; Kim, K.H. Properties of Indium-Zinc-Oxide Thin Films Prepared by Facing Targets Sputtering at Room Temperature. J. Kor. Phy. Soc. 2009, 54, 1267-1272. [CrossRef]

17. Lei, H.; Ichikawa, K.; Hoshi, Y.; Wang, M.; Uchida, T.; Sawada, Y. A study of deposition of ITO films on organic layer using facing target sputtering in Ar and Kr gases. Thin Solid Films 2010, 518, 2926-2929. [CrossRef]

18. Nose, M.; Nagae, T.; Yokota, M.; Saji, S.; Zhou, M.; Nakada, M. Electrical and colorimetric properties of TiN thin films prepared by DC reactive sputtering in a facing targets sputtering (FTS) system. Surface Coat. Technol. 1999, 116, 296-301. [CrossRef]

19. Liu, J.; Song, J.; Xiao, H.; Zhang, L.; Qin, Y.; Liu, D.; Hou, W.; Du, N. Synthesis and thermal properties of ZnAl layered double hydroxide by urea hydrolysis. Powder Technol. 2014, 253, 41-45. [CrossRef]

20. Ahmed, A.A.A.; Talib, Z.A.; Hussein, M.Z. Influence of metallic molar ratio on the electron spin resonance and thermal diffusivity of Zn-Al layered double hydroxide. J. Nanomater. 2013, 2013, 639354. [CrossRef]

21. Fang, G.; Li, D.; Yao, B.L. Fabrication and vacuum annealing of transparent conductive AZO thin films prepared by DC magnetron sputtering. Vacuum 2002, 68, 363-372. [CrossRef]

22. Smalenskaite, A.; Pavasaryte, L.; Yang, T.C.; Kareiva, A. Undoped and Eu3+ Doped Magnesium-Aluminium Layered Double Hydroxides: Peculiarities of Intercalation of Organic Anions and Investigation of Luminescence Properties. Materials 2019, 12, 736. [CrossRef] [PubMed]

23. Zaid, M.; Hafiz, M.; Matori, K.A.; Abdul Aziz, S.H.; Zakaria, A.; Ghazali, M.; Sabri, M. Effect of ZnO on the Physical Properties and Optical Band Gap of Soda Lime Silicate Glass. Int. J. Mol. Sci. 2012, 13, 7550-7558. [CrossRef] [PubMed]

24. Lu, J.G.; Fujita, S.; Kawaharamura, T.; Nishinaka, H.; Kamada, Y.; Ohshima, T.; Ye, Z.Z.; Zeng, Y.J.; Zhang, Y.Z.; Zhu, L.P.; et al. Carrier concentration dependence of band gap shift in n-type ZnO:Al films. J. Appl. Phys. 2007, 101, 083705. [CrossRef]

25. Pérez, M.R.; Pavlovic, I.; Barriga, C.; Cornejo, J.; Hermosín, M.C.; Ulibarri, M.A. Uptake of $\mathrm{Cu}^{2+}, \mathrm{Cd}^{2+}$ and $\mathrm{Pb}^{2+}$ on $\mathrm{Zn}-\mathrm{Al}$ layered double hydroxide intercalated with edta. Appl. Clay Sci. 2006, 32, 245-251. [CrossRef]

(C) 2020 by the authors. Licensee MDPI, Basel, Switzerland. This article is an open access article distributed under the terms and conditions of the Creative Commons Attribution (CC BY) license (http://creativecommons.org/licenses/by/4.0/). 